\title{
PCR analysis of the effect of photodynamic therapy on breast tumors
}

\author{
Análise por PCR do efeito da terapia fotodinâmica em tumores mamários \\ Análisis por PCR del efecto de la terapia fotodinámica sobre tumores de mama
}

Received: 09/10/2021 | Reviewed: 09/20/2021 | Accept: 09/25/2021| Published: 09/26/2021

\author{
Isabelle Ferreira \\ ORCID: https://orcid.org/0000-0001-6156-6954 \\ Universidade do Vale do Paraíba, Brazil \\ E-mail: iferreira@univap.br \\ Glenda Nicioli da Silva \\ ORCID: https://orcid.org/0000-0001-9751-3379 \\ Universidade Federal de Ouro Preto, Brazil \\ E-mail: glenda_silva@yahoo.com \\ Juliana Ferreira-Strixino \\ ORCID: https://orcid.org/0000-0001-7128-6817 \\ Universidade do Vale do Paraíba, Brazil \\ E-mail: juferreira@univap.br \\ Clovis Grecco \\ ORCID: https://orcid.org/0000-0002-1680-7728 \\ Centro de Estudos e Formação Avançada, Brazil \\ E-mail: clovis.grecco@alumni.usp.br \\ Vanderlei Salvador Bagnato \\ ORCID: https://orcid.org/0000-0003-4833-239X \\ Universidade de São Paulo, Brazil \\ E-mail: vander@ifsc.usp.br \\ Daisy Maria Favero Salvadori \\ ORCID: https://orcid.org/0000-0001-9323-3134 \\ Universidade Estadual Paulista, Brazil \\ E-mail: dfavero@fmb.unesp.br \\ Juliana Guerra Pinto \\ ORCID: https://orcid.org/0000-0002-7356-1576 \\ Universidade do Vale do Paraíba, Brazil \\ E-mail: jgbiomd@gmail.com \\ Noeme Sousa Rocha \\ ORCID: https://orcid.org/0000-0001-9676-116X \\ Universidade Estadual Paulista, Brazil \\ E-mail: rochanoeme@fmvz.unesp.br
}

\begin{abstract}
Photodynamic therapy (PDT) is a promising therapeutic modality for treating cancer, including breast tumors. The oxidative damage caused by PDT culminates in cell death, induction of immune response, and the resulting destruction of the tumor. This study aimed to evaluate the gene expression profiling of genes BCL-2, BAX, and HER-2 and their proteins after PDT, associating it with the necrosis caused by this therapy under different fluences. Twenty-eight female rats received a single dose of 7,12-dimethylbenz (a) anthracene (DMBA - 80mg/kg), by gavage, for breast tumor induction. After the tumors grew, the animals were divided into four groups: G1 - control group - untreated breast tumor - and G2, G3, and G4 groups treated with PDT using Photogem@ as photosensitizer and interstitial irradiation, with fluences of $50 \mathrm{~J} / \mathrm{cm}, 100 \mathrm{~J} / \mathrm{cm}$, and $150 \mathrm{~J} / \mathrm{cm}$, respectively. Samples of tumors were harvested for histological examination by RT-qPCR. The RT-qPCR showed that the gene expression profiling of BCL-2, BAX, and HER-2 was not altered after PDT. Hemorrhagic necrosis and qualitatively greater vascular and cellular damage were observed and correlated positively with the fluence. PDT does not seem to induce the modulation of genes related to apoptosis. The results indicate that the type of cell death stimulated by PDT in breast tumor is necrosis.
\end{abstract}

Keywords: Cancer; Gene expression; Photodynamic therapy.

\section{Resumo}

A terapia fotodinâmica (TFD) é uma modalidade terapêutica promissora para o tratamento do câncer, incluindo tumores de mama. Os danos oxidativos causados pela TFD culminam na morte celular, indução da resposta imune e na consequente destruição do tumor. Este estudo teve como objetivo avaliar o perfil de expressão genética dos genes BCL2, BAX e HER-2 e suas proteínas após o TFD, associando-o à necrose causada por essa terapia sob diferentes fluências. Vinte e oito ratas receberam uma única dose de 7,12 - dimetilbenzantraceno (DMBA - 80mg/kg), por gavage, para indução de tumor de mama. Após o crescimento dos tumores, os animais foram divididos em quatro grupos: G1 - grupo 
controle - tumor de mama não tratado - e grupos G2, G3 e G4 tratados com PDT usando Photogem@ como fotosensibilizante e irradiação intersticiais, com fluências de $50 \mathrm{~J} / \mathrm{cm}, 100 \mathrm{~J} / \mathrm{cm}$ e $150 \mathrm{~J} / \mathrm{cm}$, respectivamente. Amostras de tumores foram colhidas para exame histológico por RT-qPCR. O RT-qPCR mostrou que o perfil de expressão genética de BCL-2, BAX e HER-2 não foi alterado após o TFD. Necrose hemorrágica e dano vascular e celular qualitativamente maior foram observados e correlacionados positivamente com a fluência. O TFD não parece induzir a modulação de genes relacionados à apoptose. Os resultados indicam que o tipo de morte celular estimulada pelo TFD no tumor mamário é a necrose.

Palavras-chave: Câncer; Expressão genética; Terapia fotodinâmica.

\begin{abstract}
Resumen
La terapia fotodinámica (TFD) es una modalidad terapéutica prometedora para el tratamiento del cáncer, incluidos los tumores de mama. El daño oxidativo causado por la TFD culmina en la muerte celular, la inducción de la respuesta inmune y la consiguiente destrucción del tumor. Este estudio tuvo como objetivo evaluar el perfil de expresión genética de los genes BCL-2, BAX y HER-2 y sus proteínas después de TFD, asociándolo con necrosis causada por esta terapia bajo diferentes fluencias. Veintiocho ratas recibieron una dosis única de 7,12 7,12 - dimetilbenzantraceno (DMBA - 80 $\mathrm{mg} / \mathrm{kg}$ ), por sonda, para la inducción del tumor de mama. Después del crecimiento tumoral, los animales se dividieron en cuatro grupos: G1 - grupo control - tumor de mama no tratado - y grupos G2, G3 y G4 tratados con PDT utilizando Photogem@ como fotosensibilizador intersticial e irradiación, con fluencias de $50 \mathrm{~J} / \mathrm{cm}, 100 \mathrm{~J} / \mathrm{cm} \mathrm{y} 150 \mathrm{~J} / \mathrm{cm}$, respectivamente. Se recogieron muestras tumorales para su examen histológico mediante RT-qPCR. RT-qPCR mostró que el perfil de expresión genética de BCL-2, BAX y HER-2 no se alteró después de la TFD. Se observó necrosis hemorrágica y un daño vascular y celular cualitativamente mayor y se correlacionaron positivamente con la fluidez. TFD no parece inducir la modulación de genes relacionados con la apoptosis. Los resultados indican que el tipo de muerte celular estimulada por la TFD en el tumor de mama es la necrosis.
\end{abstract}

Palabras clave: Cáncer; Expresión genética; Terapia fotodinâmica.

\title{
1. Introduction
}

Photodynamic therapy (PDT) is a promising therapeutic modality used for the treatment of cancer and other ailments. The induction of oxidative stress and formation of reactive oxygen species (ROS) result in organelle damage, culminating in cell death and destruction of the tumor or abnormal tissue after PDT (Oleinick \& Evans, 1998). Apoptosis is a common mechanism of cell death in this case; however, the triggering events responsible for the PDT-mediated apoptotic response are not clear. Understanding the mechanisms involved in PDT-induced apoptosis may improve therapeutic efficacy (Srivastava et al. 2001), contributing to the knowledge on treatment failures (Itoh et al. 2000; Senderowicz, 2004).

PDT could be used as an alternative treatment for the control of tumor growth or as an adjunct therapy to surgery, in order to avoid recurrence. A previous study conducted by our research group showed that PDT decreased the rate of tumor growth, although the remission of the tumor was not complete. Endogenous factors could be associated with the unsatisfactory results (Ferreira et al. 2012). As a consequence, the authors emphasized the need for more comprehensive studies, investigating the action of endogenous components in the success of PDT.

Some studies have shown that the anti-apoptotic protein Bcl-2 is the target of photosensitizers. Bcl-2 sequesters proapoptotic molecules, such as Bax and Bak, inhibit apoptosis. Moreover, Bcl-2 prevents the release of potent mitochondrial activators of the cytosolic death effector proteases, which mediate the intracellular proteolysis typical of apoptosis. Therefore, the downregulation of Bcl-2 and related proteins may result in triggering apoptosis (Srivastava et al. 2001; Kessel \& Arroyo, 2007).

The discovery of the role of the HER2 gene was one of the milestones in breast cancer research over the past two decades. Breast cancer in women is one of the major causes of death in both developed and developing countries (Ahmed et al. 2012). It is estimated that the incidence of breast cancer has increased by $20 \%$ since 2008 , and mortality by $14 \%$, these data show that the spread of breast cancer is significant (Alteri et al. 2013; Pitta et al. 2021). HER2 + tumors exhibit faster growth and present higher metastatic capacity compared to HER2-tumors (Hicks et al. 2008). In addition, some authors have claimed that this gene seems to be an important contributor to the antiproliferative response to PDT, interfering with the necrosis and 
apoptosis processes and tumor destruction (Martinez-Carpio \& Trelles, 2010).

The aim of this study was to investigate the gene profiling expression of BCL-2/Bcl-2, BAX/Bax, and HER2/erbB2 genes in tumors treated with PDT under different fluences compared to untreated tumors. The signals that trigger cell death and the cascade of events leading to apoptosis are today important targets in the search for new anticancer therapy.

\section{Materials and Methods}

This research is in accordance with the Ethical Principles in Animal Experimentation and was approved by the Ethics Committee of the Faculty of Veterinary Medicine and Animal Science-UNESP-Botucatu (protocol: 72/2009).

\subsection{Experimental design}

A total of 28 young Sprague-Dawley female rats weighing between $200-250 \mathrm{~g}$ was used in this study. The animals remained in the ideal conditions of temperature $\left(22 \pm 2^{\circ} \mathrm{C}\right)$, humidity $(50 \pm 20 \%)$, and light (12h light: $12 \mathrm{~h}$ dark cycle). Feed and water were provided ad libitum. Breast cancer was induced by a single dose of $80 \mathrm{mg} / \mathrm{kg}$ 7,12-dimethylbenz (a) anthracene (DMBA - Sigma-Aldrich) dissolved in soybean oil, administered by gavage.

The animals were submitted daily to the inspection of viability and weekly to the clinical evaluation until tumor development. Then, the height (L1), width (L2), and length (L3) of the tumor masses were measured with the aid of a caliper.

Regarding the cytological diagnostic, the slides were stained with Giemsa and examined under an optical microscope at 400X magnification. The cytological criteria were based on Karim et al. (2008) with modifications.

The animals were divided into four groups with seven animals in each group. The groups were divided according to different fluences and irradiation times.

- G1 - control - untreated breast tumor

- G2 - tumors submitted to PDT with fluence of $50 \mathrm{~J} / \mathrm{cm} 2$

- G3 - tumors submitted to PDT with fluence of $100 \mathrm{~J} / \mathrm{cm} 2$

- G4 - tumors submitted to PDT with fluence of $150 \mathrm{~J} / \mathrm{cm} 2$

These doses were based on the Silva et. al, 2014.

Haematoporphyrin (Photogem®; Photogem LLC Company, Moscow, Russia) was used as photosensitizer at $12 \mathrm{mg} / \mathrm{kg}$, administered intraperitoneally to all the animals. Regarding PDT application, the light source was a laser diode Ceralas Ceramoptec $630 ®$, Germany, at a wavelength of $630 \mathrm{~nm}$. The amount used was $200 \mathrm{~mW} / \mathrm{cm} 2$.

In order to perform the PDT, the animals were anesthetized intramuscularly with $20 \mathrm{mg}$ xylazine $2 \%(0.2 \mathrm{ml} / 100 \mathrm{~g} \mathrm{bw}$; Vetbrands®, Brazil) and ketamine $50 \mathrm{mg}$ (Vetaset, Fort Dodge, Brazil). The animals received the photosensitizer by intraperitoneal administration and 24 hours later, the laser irradiation was carried out using an optic fiber with a diffuser $(1 \mathrm{~cm})$ coupled to a laser with $250 \mathrm{~s}$ (Group 2), $500 \mathrm{~s}$ (Group 3), and $750 \mathrm{~s}$ (Group 4) fluences. The diffusing fiber was inserted into the tumor central part, ensuring total tumor irradiation.

The animals were anesthetized with isoflurane 30 hours after irradiation and then euthanized by transection of the jugular veins.

\subsection{Histopathology}

A tumor fragment of each animal was collected for histopathological preparation. The histopathological material was fixed with $10 \%$ buffered formalin, then embedded in paraffin, and stained with hematoxylin and eosin (HE). In the histological preparations, morphological differences and points of necrosis in the treated tumor groups were analyzed and compared to the 
control group. A comparison was also performed between the fluences used and the depth of necrosis observed in the breast tissue.

\subsection{Reverse transcription-quantitative PCR (RT-qPCR)}

Samples of tumors were collected and immediately frozen in liquid nitrogen and then conditioned at $-80 \circ \mathrm{C}$. The extraction of total RNA from the samples was performed using the RNeasy Mini Kit (Qiagen, Hilden, Germany), according to the protocol provided by the manufacturer. Then, the concentration and purity of the RNA was assessed using a spectrophotometer (NanoVue - EG).

Complementary DNA was synthesized from $0.1 \mathrm{~g}$ of total RNA using the High-Capacity Kit (Applied Biosystems, Branchburg, New Jersey, USA), according to the instructions of the manufacturer. The reactions were incubated at $25^{\circ} \mathrm{C}$ for 10 min and $37{ }^{\circ} \mathrm{C}$ for $120 \mathrm{~min}$, and then remained at $4{ }^{\circ} \mathrm{C}$. The samples were stored at $-20 \circ \mathrm{C}$.

The BCL-2 (Rn00566561_m1), BAX (Rn99999125_m1), and HER2 (Rn01480159_g1) gene expression levels were assessed using the TaqMan system (Applied Biosystems, Foster City, CA, USA). The $\beta$-actin was used as a housekeeping gene. Each tube contained $2 \mu \mathrm{L}$ of cDNA template, $5 \mu \mathrm{L}$ of TaqMan 2X Master Mix (Applied Biosystems), $2.5 \mu \mathrm{L}$ of water, and 0.5 $\mu \mathrm{L}$ of $20 \mathrm{X}$ primers/probes (Assays-on-Demand gene expression products, Applied Biosystems). The reaction was performed under the following thermal cycling conditions: $94{ }^{\circ} \mathrm{C}$ for $10 \mathrm{~min}$, followed by 40 cycles of $94{ }^{\circ} \mathrm{C}$ for $30 \mathrm{~s}$, and $60{ }^{\circ} \mathrm{C}$ for $1 \mathrm{~min}$. Fluorescence data were collected during each annealing/extension step. The efficiency of the primers was assessed with standard curves, with the $\beta$-actin, BCL-2, BAX, and HER-2 primers presenting efficiencies above $90 \%$. The reactions were performed using the 7500 FAST Real-Time PCR System (Applied Biosystems) and the SDS software, version 1.2.3 (Sequence Detection Systems 1.2.3, 7500 Real-Time PCR Systems, Applied Biosystems). In order to prevent contamination, a negative control (without DNA) was added for each plate. The relative gene expression data were analyzed using the $2-\Delta \Delta C T$ method (Livak \& Schmittgen, 2001). An RQ (Relative quantification) $<0.5$ was considered as a decreased gene expression, and an RQ> 2.00 was regarded as an increased gene expression.

\subsection{Statistical analysis}

Statistical analyses were performed using SAS software, version 9.2 (Statistical Analysis System, SAS Institute, Cary, NC, USA). The results were compared using the test of analysis of variance (ANOVA) to detect statistical differences between experimental groups. The Student $t$ test was used to evaluate the difference between the averages of the groups. The results were considered statistically significant at $\mathrm{p}<0.05$.

\section{Results}

\subsection{Cytological examination}

Five weeks after DMBA administration, 100\% of animals developed breast cancer. The preferential localization of the tumor was in the cervicothoracic region (61.2\%), regardless of the time of clinical onset of the injury. Among the animals, eight (28.5\%) had multiple tumors. Tumor size ranged from $1.1 \times 0.7 \times 0.8 \mathrm{~cm}$ to $2.6 \times 1.3 \times 1.0 \mathrm{~cm}$.

All developed tumors that were diagnosed by cytological examination were malignant. Based on the malignancy criteria described by Karim et al. (2008), the tumors showed high cellularity, anisokaryosis, anisocytosis, loose chromatin, and prominent nucleoli. 


\subsection{Histopathology}

The neoplastic morphological types evidenced by HE staining were classified as recommended by Russo et al. (2000) in the following three classes: tubular carcinoma (16 cases), ductal ( 9 cases), and papillary ductal ( 3 cases). The qualitative analysis showed that there was no necrosis in the untreated tumor (Figure 1). In the tumors subjected to PDT, the higher the fluence, the greater was the area of necrosis.

Figure 1 - A. TFD-induced necrohemorrhagic area. Coagulation necrosis can be evidenced by eosinophilia and the maintenance of tissue architecture. B. PDT - induced necrohemorrhagic area. C. Bax immunoexpression in DMBA-induced breast carcinoma in Sprague-Dawley rats. Cytoplasmic staining of neoplastic cells (score 3). D. Bcl-2 immunoexpression in DMBA-induced breast carcinoma in female Sprague-Dawley rats. Cytoplasmic staining of neoplastic cells (score 2). E. Immunoexpression of c-erbB2 in DMBA-induced breast carcinoma in Sprague-Dawley rats. Membrane and cytoplasmic marking of neoplastic cells score 3).
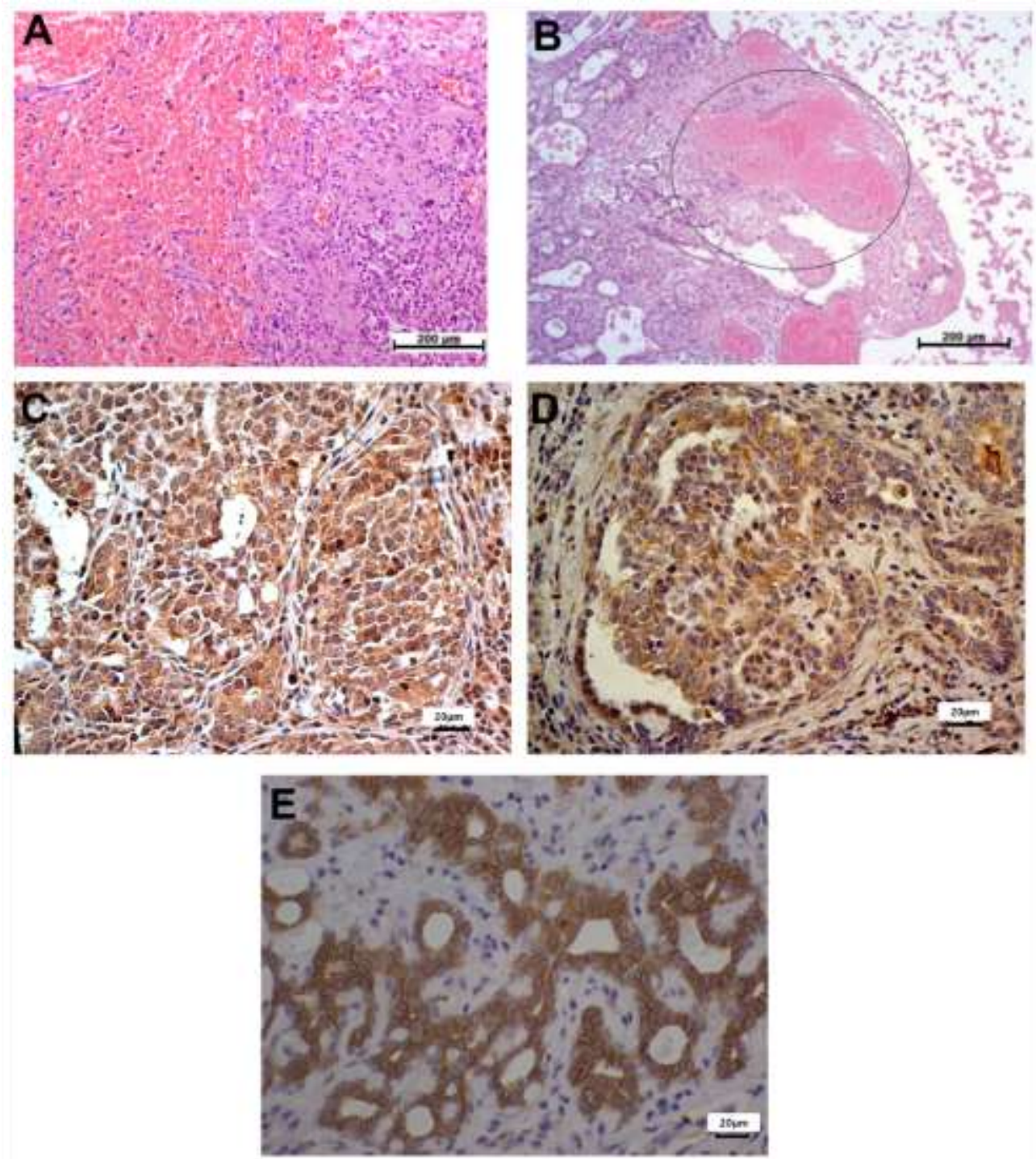

Source: Authors.

\subsection{RTq-PCR}

Concerning the gene expression, the analysis of BCL-2 gene showed seven cases (25\%) with higher expression: three were the group treated with $150 \mathrm{~J} / \mathrm{cm} 2(\mathrm{G} 4)$, two were the group treated with $100 \mathrm{~J} / \mathrm{cm} 2$ (G3), one was the group treated with $50 \mathrm{~J} / \mathrm{cm} 2(\mathrm{G} 2)$, and one was the control group $(\mathrm{G} 1)(\mathrm{RQ}=2.07$ to 7.43). The sample that showed decreased expression in BCL- 
2 also belongs to the $\mathrm{G} 4$ group $(4 \%)(\mathrm{RQ}=0.21)$. The other samples (20 cases) exhibited normal gene expression $(\mathrm{RQ}=0.56$ to 1.71). The expression level of this gene ranged from 0.56 to 7.43 , with a mean of $+1.87 /-1.68$. There was no significant statistical change in the expression of this gene among the different groups (Figure 2A).

Figure 2 - (A) Comparison between mean levels of $B C L-2$ gene expression by qRT-PCR. (B) Figure 2 - Comparison between mean levels of genes expression by qRT-PCR were G1 - control group; G2 - tumors submitted to PDT with fluence of $50 \mathrm{~J} / \mathrm{cm}^{2}$; G3 - tumors submitted to PDT with fluence of $100 \mathrm{~J} / \mathrm{cm}^{2} ; \mathrm{G} 4$ - tumors submitted to PDT with fluence of $150 \mathrm{~J} / \mathrm{cm}^{2}$. (A) Comparison between mean levels of $B C L-2$ gene expression by qRT-PCR. (B) Comparison between mean levels of $B A X$ gene expression by qRT-PCR. (C)- Comparison between mean levels of HER2 gene expression by qRT-PCR.
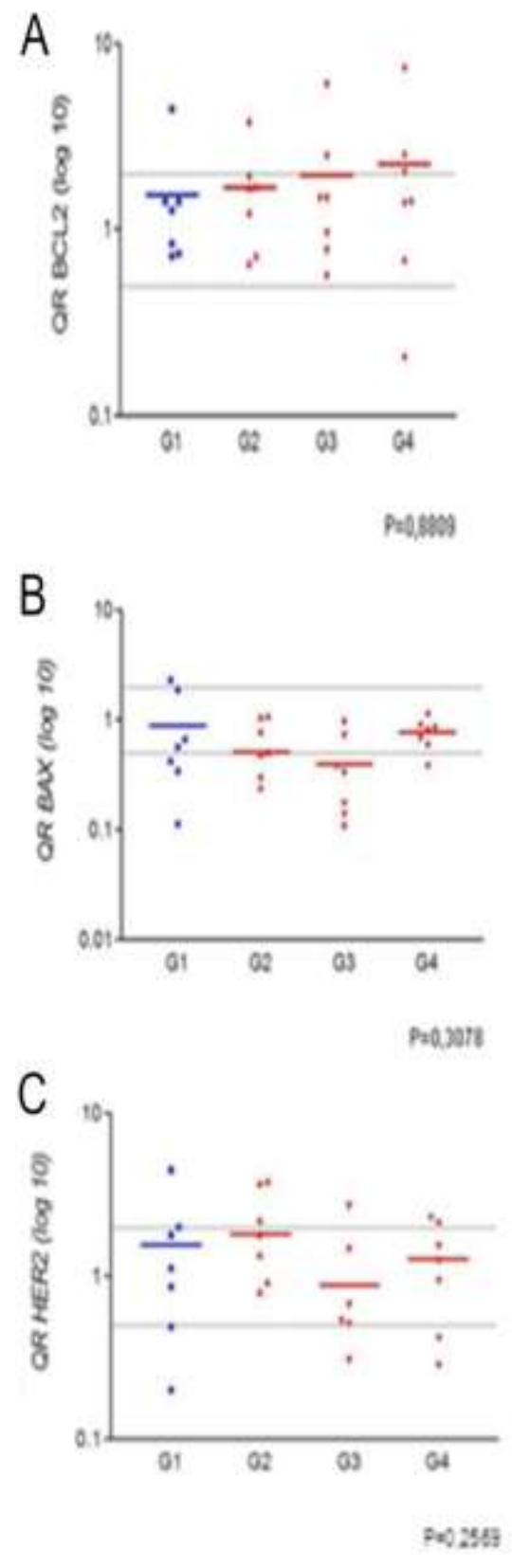

Source: Authors.

The results for the BAX gene expression revealed greater expression in the control group (G1) (4\%) with increased expression $(\mathrm{RQ}=2.31)$. Of the 12 cases with decreased expression, five belonged to the group treated with a fluence of $100 \mathrm{~J} /$ 
$\mathrm{cm} 2$ (G3), three belonged to the group treated with a fluence of $50 \mathrm{~J} / \mathrm{cm} 2$ (G2), three belonged to the control group (G1), and one belonged to the group treated with fluence and $150 \mathrm{~J} / \mathrm{cm} 2$ (G4) (43\%) (RQ $=0.10$ to 0.49). The other samples (15 cases) exhibited normal expression $(\mathrm{RQ}=0.51$ to 1.87 ). The expression of this gene ranged from 0.1 to 2.31 , with a mean of $0.68+/-$ 0.51. There was no statistically significant change in the expression of this gene between the different groups (Figure 2B).

The analysis of HER-2 gene showed eight samples with increased expression, three were treated with fluence of 50 $\mathrm{J} / \mathrm{cm} 2(\mathrm{G} 2)$, two were treated with fluence of $150 \mathrm{~J} / \mathrm{cm} 2(\mathrm{G} 4)$, two were control group (G1), and one was treated with fluence of $100 \mathrm{~J} / \mathrm{cm} 2$ (G3) (29\%) (RQ = 2.01 to 4.48). The six cases with decreased expression were equally distributed among G1, G3, and G4 groups $(21 \%)(\mathrm{RQ}=0.00$ to 0.48$)$. No sample from $\mathrm{G} 2$ showed decreased expression. The other samples (14 cases) had normal expression $(\mathrm{RQ}=0.51$ to 1.81 ). The level of expression for this gene ranged from 0.00 to 4.48 , with a mean of $1.46+/-$ 1.16. There was no significant statistical difference in the expression of this gene between the different groups (Figure $2 \mathrm{C}$ ).

\section{Discussion}

The chemically-induced mammary tumors in rodents are widely used models for the study of cancer pathogenesis and molecular mechanisms involved in the triggering and progression of the neoplastic process (Russo \& Russo, 1996; Vohra et al. 2021). However, the use of this model in the study of PDT is rare. There are anatomical and physiological similarities between the model used in this study and female human beings (Russo et al. 1990; Heffelfinger et al. 2000).

Mammary tumors induced by a single dose of DMBA vary morphologically from hyperplasia to adenomas and carcinomas (Terada et al. 1995; Kocdor et al. 2000; Barros et al. 2004; ). In the present study, the diagnosed malignant neoplasm showed that the model was properly established.

The type of necrosis observed in tumors treated with PDT was hemorrhagic necrosis. Comparing the fluences and the depth of the breast tissue necrosis, this study revealed that the higher the fluence, the greater is the area of necrosis and vascular injury. When the photosensitizers were administered to the patient at a given concentration and received proper irradiance, a series of reactions was triggered, resulting in the formation of reactive oxygen species (ROS), inducing cell death. The amount of free radicals produced during therapy generally depends on the fluence applied to the tissue (George \& Abrahamse 2016; Duanmu et al. 2011; Wyld et al. 2001).

Irradiation of bulky tumors can be achieved through optical fibers with attached cylindrical diffuse fiber tips. Depending on the volume to be treated, several fiber diffusers can be positioned simultaneously inside the tumor. One of the challenges for diffusers is to provide a homogeneous light emission, leading to variations in emission intensity, influencing the distribution of light in the tissue. It is known that this heterogeneity in the emission profile of cylindrical light diffusers interferes with the distance and depth of light distribution, which can lead to different concentrations of ROS in the tissue. In addition, the heterogeneity of tumor tissue also interferes with light distribution and, consequently, with the production of ROS, considering that there are several absorbers, spreaders in the tissue, as well as the presence of necrotic tissue. These factors can affect the effectiveness of PDT and the type of cell death (Investigation of non-uniformly emitting optical fiber diffusers on the light distribution in tissue) (Ströbl et al. 2020).

Chiu et al. (2003). demonstrated that the cell lines of human prostate cancer DU - 145 are resistant to PDT-induced apoptosis due to the absence of the Bax gene. Moreover, according to Srivastava et al.(2001), the treatment of RIF1 cells (mouse tumor model system) with PDT (Pc 4 - Phthalocyanines) resulted in down-regulation of the Bcl-2 gene, which could trigger the apoptotic pathway. The damage caused to Bcl-2 by PDT was also described by Xue et al. (2001). In our study, all the DMBAinduced mammary tumors expressed protein and Bcl-2 and Bax genes, which could prevent the apoptotic process. The PDTinduced cell death observed in our study resulted from necrosis, as confirmed by histopathology. Conflicting results could be 
explained by different cell culture, different photosensitizers, different radiation parameters, different Drug Light Interval, and time between treatments and euthanasia of the animals.

The inhibition and/or degradation of the erb-B2 protein after the completion of the PDT treatment, as demonstrated by Koval et al. (2010) and reported by Martinez-Carpio et al. (2010) apparently occurred also in this study due to the low expression of erbB2, regardless of the fluences [27]. According to Appert-Collin [28], the ErbB2 receptor is related to the progression of the breast tumor and signs of malignancy, such as migration and invasion, and its overexpression is usually associated with several types of cancer. The clinical study by Zheng et al. (2019) found a clinical correlation between a higher serum concentration of the HER2 extracellular domain (ECD) and worsening in several patients. Thus, a reduction in HER-2 expression and a consequent reduction in the ErbB2 protein may be a positive indicator of PDT success (Appert-Collin et al. 2015).

Modulation of $B A X, B C L 2$, and $H E R-2$ gene expression was not observed between the control and the groups treated with PDT. Differences observed between the gene level and protein expression observed in our study could be explained by epigenetic abnormalities such as the modification of $\mathrm{CpG}$-island methylation (Yeh et al. 2003) or post-translational modifications.

The DLI (Drug-light interval) affects the response to PDT. When a hematoporphyrin (photosensitizer) is used and a large interval is adopted, the action of PDT is cellular. However, if a smaller interval is used, the vascular response is predominant. Thus, the PDT may be associated with the inhibition or activation of several genes involved in cell death.

Another factor is the type of photosensitizer used. According to Luo et al. (1997), the Bcl-2 family genes may be affected differently depending on the PS used. The Photogem photosensitizer used in this study is a complex mixture of monomeric and aggregated porphyrins that causes damage to the mitochondria when activated by light, also affecting gene expression (Perlin et al. 1985). Photosensitizers located in the mitochondria often cause cell death by apoptosis (Peng \& Nesland 1996; Graham et al. 2003). The Phthalocyanines are macrocyclic compounds of synthetic origin whose structure is formed by units of isoindol kept together by nitrogen bridges. The PC4, a photosensitizer used in most mentioned studies, will connect to the mitochondria, endoplasmic reticulum, and the Golgi complex (Usuda et al. 2003). The Hypericin, another photosensitizer also mentioned, is a type of antroperilene quinine photoactive pigment found in plants of the genus Hypericum. It targets mainly mitochondria, and one of its main advantages over porphyrin compounds is its low tendency to aggregate (Diwu \& Lown, 1990; Halder at al. 2005). Therefore, they represent different molecules with different degrees of aggregation that might affect the penetration of the photosensitizer in the cell. Furthermore, the concentration of the photosensitizer, its affinity for different organelles, and its distribution may also influence the response mechanisms to PDT (Teiten et al. 2003).

Silva et al. (2014) suggested that the apoptosis induction is directly dependent on the duration of the tissue therapy, and that the increased expression of pro-apoptosis genes and decreased expression of anti-apoptotic genes in photodynamic therapy indicates that these genes are more directly involved with the PDT-induced apoptosis, using PDZ as a photosensitizer. These results showed the importance of these genes in activating PDT-induced apoptosis.

Another factor that affects the evaluation of the PDT response is the time of analysis of the post-PDT sample. Depending on this period, we might have observed other pathways of cell death such as necroptosis and pyroptosis. There are many doubts regarding the role of necroptosis in the development of neoplasms. There are indications that necroptosis inhibition is a strategy against metastases. Cancer cells may also show decreased necroptosis mediators, suggesting that this pathway of cell death may negatively regulate carcinogenesis (Najafov et al. 2017). Pyroptosis is a cell death pathway dependent on caspases. This pathway is activated by specific inflammatory agents, leading to the death of neoplasic cells, inhibiting their proliferation, and assisting in the prevention of metastases (Fang et al. 2020). 


\section{Conclusion}

PDT does not seem to induce the modulation of genes related to apoptosis under the irradiation parameters used with Photogem and analyzed after 30h of therapy. The results of this study indicate that the type of cell death stimulated by PDT in breast tumors is necrosis under the conditions of this study. This study provides data preliminary studies on the effect of photodynamic therapy in breast cancer and should be explored in future studies.

\section{Acknowledgements}

The authors are greatly indebted to FAPESP (Fundação de Amparo a Pesquisa do Estado de São Paulo - Processes No. 09/51826-0 and No. 11/00731-0) for financial support, to CePOF-IFSCUSP (Optics and Photonics Research Center - Instituto de Física de São Carlos - Universidade de São Paulo) for the equipment provided (Laser and photosensitizer), and to José Dirceu Vollet Filho and Marilia Porto for scientific guidance.

\section{References}

Ahmed, A., Ali, A., Ali, S., Ahmad, A., Philip, P \& Sarkar, F. (2012). Breast Cancer Metastasis and Drug Resistance, 1-18.

Alteri, R., Barnes, C., Burke, A., et al. (2013). American cancer society. Breast Cancer Facts \& Figures, $2013-2014$.

Appert-Collin, A. et al. (2015). Role of ErbB receptors in cancer cell migration and invasion. Frontiers in Pharmacology, 6, 1-10.

Barros, A. C. S. D., Muranaka, E. N. K., Mori, J. L., et al. (2004). Induction of experimental mammary carcinogenesis in rats with 7,12 Dimethylbenz(a)anthracene. Rev. Hosp. Clín. 59, 257-261.

Chiu, S. M., Xue, L.Y., Usuda, J., Azizuddin, K., \& Oleinick, N. L. (2003). Bax is essential for mitochondrion-mediated apoptosis but not for cell death caused by photodynamic therapy. Brit. J. Cancer; 89, 1590-1597.

Diwu, Z., \& Lown, J. W. (1990). Hypocrellins and their use in photosensitization. Photochem. Photobiol. 52, $609-616$.

Duanmu, J. et al. (2011). Effective treatment of chemoresistant breast cancer in vitro and in vivo by a factor VII-targeted photodynamic therapy. British journal of cancer, 104, 9, 1401-1409.

Fang, Y., Tian, S., Pan, Y., Li, W., Wang, Q., Tang, Y., Yu, T., et al. (2020). Pyroptosis: A new frontier in cancer. Biomedicine \& Pharmacotherapy, $121,1095952$.

Ferreira, I., Ferreira, J., Vollet-Filho, J. D., et al. (2012). Photodynamic therapy for the treatment of induced mammary tumor in rats. Lasers Med. Sci. 28, 571577. DOI 10.1007/s10103-012-1114-3.

George, B. P. A. \& Abrahamse, H. (2016). A Review on Novel Breast Cancer Therapies Photodynamic Therapy. Anti-Cancer Agents in Medicinal Chemistry, $16,793-801$.

Graham, A., Li, G., Chen, Y. et al. (2003). Structure-activity relationship of new octaethylporphyrin-based benzochlorins as photosensitizers for photodynamic therapy. Photochem Photobiol, 77,561-566.

Halder, M., Chowdhury, P., Gordon, M., \& Petrich, J. (2005). Hypericin and its perylene quinone analogs: probing structure, dynamics, and interactions with the environment. Adv. Photochem. 28. 10.1002/0471714127.ch1

Heffelfinger, S. C., Gear, R. B., Taylor, K. et al. (2000). DMBA-induced mammary pathologies are angiogenic in vivo and in vitro. Lab. Invest. 80, 485-92.

Hicks, D. G., \& Kulkarni, S. (2008). HER2+ Breast Cancer: Review of Biologic Relevance and Optimal Use of Diagnostic Tools. Am. J. Clin. Pathol. 129, 263273 .

Itoh, M., Chiba, H., Noutomi, T., Takada, E. \& Mizuguchi, J. (2000). Cleavage of Bax-alpha and Bcl-x (L) during carboplatin-mediated apoptosis in squamous cell carcinoma cell line. Oral Oncol. 36, 277-285.

Karim, B. O., Ali, S. Z., Landolfi, J. A., et al. (2008). Cytomorphologic differentiation of benign and malignant mammary tumors in fine needle aspirate specimens from irradiated female Sprague-Dawley rats. Vet. Clin. Pathol. 37, 229-236.

Kessel, D. \& Arroyo, A. S. (2007). Apoptotic and autophagic responses to Bcl-2 inhibition and photodamage. Photoch. Photobio. Sci. 6, 1290-1295.

Kocdor, H., Cehreli, R., Kocdor, M. A., Sis, B., Yilmaz, O., Canda, T., Demirkan, B., Resmi, H., Alakavuklar, M. \& Harmancioglu, O. (2000). Toxicity induced by the chemical carcinogen 7,12-dimethylbenz[a]anthracene and the protective effects of selenium in Wistar rats. J. Toxicol. Env. Heal. A. 68, 693-701.

Koval, J., Mikes, J., Jendzelovsky, R., Kello, M., Solar, P. \& Fedorocko, P. (2010). Degradation of HER2 Receptor Through Hypericin-mediated Photodynamic Therapy. Photochem Photobiol, 86, 200-205. 
Livak, K. J. \& Schmittgen, T. D. (2001). Analysis of relative gene expression data using real-time quantitative PCR and the 2(-Delta Delta C(T)). Method. Methods. 25, 402-408.

Luo, Y. \& Kessel, D. (1997). Initiation of apoptosis versus necrosis by photodynamic therapy with chloroaluminum phthalocyanine. Photochem Photobiol 66:479-483 20

Martinez-Carpio, P. A. \& Trelles, M. A. (2010). The role of epidermal growth factor receptor in photodynamic therapy: a review of the literature and proposal for future investigation. Lasers Med. Sci. 25, 767-771.

Najafov, A., Hongbo, C., \& Yuan, J. (2017). Necroptosis and Cancer. Trends Cancer, 3, 4, 294-301. 10.1016/j.trecan.2017.03.002.

Oleinick, N. L.\& Evans, H. H. (1998). The photobiology of photodynamic therapy: cellular targets and mechanisms. Radiat. Res.,150, 146-156.

Peng, Q., Moan, J \& Nesland, J.M. (1996). Correlation of subcellular and intratumoral photosensitizer localization with ultrastructural features after photodynamic therapy. Ultrastruct Pathol, 20, 109-129.

Perlin, D. S., Murant, R. S., Gibson, S. L. \& Hilf, R. (1985). Effects of Photosensitization by Hematoporphyrin Derivative on Mitochondria Adenosine Triphosphatase-mediated Proton Transport and Membrane Integrity of R3230AC Mammary Adenocarcinoma. Cancer Res. 45, 653-658.

Pitta, M. G. R., Silva, R. P. S. \& Alves, G. V. S. (2021). Nanocarreadores aplicados ao tratamento do câncer de mama. Research, Society and Development, 10, 10, http://dx.doi.org/10.33448/rsd-v10i10.18966.

Russo, J \& Russo, I. H. (1996). Experimentally induced mammary tumors in rats. Breast Cancer Res. Tr., 39, 7-20.

Russo, J. \& Russo, I. H. (2000). Atlas and histologic classification of tumors of the rat mammary gland. J. Mammary Gland. Biol. 5, 187-200.

Russo, J., Russo, I. H., Rogers, A.E., Van Zwieten, M. J. \& Gusterson, B. A. (1990) Tumors of the mammary gland. IARC Scientific Publications. $99,47-78$.

Senderowicz, A. M. (2004). Targeting cell cycle and apoptosis for the treatment of human malignancies. Curr. Opin. Cell. Biol. 16, 670-678.

Silva, J. C., Ferreira-Strixino, J., Fontana, L. C., Paula, L. M., Raniero, L., Martin A. A., Canevari, R. (2014). A. Apoptosis-associated genes related to photodynamic therapy in breast carcinomas. Lasers Med Sci, 29, 1429-1436.

Srivastava, M., Ahmad, N., Gupta, S. \& Mukhtar, H. (2001). Involvement of Bcl-2 and Bax in photodynamic therapy-mediated apoptosis. Antisense Bcl-2 oligonucleotide sensitizes RIF 1 cells to photodynamic therapy apoptosis. J. Biol. Chem. 276, 15481-15488.

Ströbl, S., Domke, M., Rühm, A. \& Srok, R. (2014). Investigation of non-uniformly emitting optical fiber diffusers on the light distribution in tissue. Biomedical Optics Express, 11, 7.

Teiten, M. H., Bezdetnaya, L., Morlière, P., Santus, R. \& Guillemin, F. (2003). Endoplasmic reticulum and Golgi apparatus are de preferential sites of Foscan localization in cultured tumor cells. Brit J Cancer, 88, 1, 146-152.

Terada, S., Uchide, K., Suzuki, N., Akasofu, K. \& Nishida, E. (1995). Induction of ductal carcinomas by intaductal administration of 7,12 dimethylbenz(a)anthracene in Wistar rats. Breast Cancer Res. Tr., 34, 35-43.

Usuda, J., Azizuddin, K., Chiu, S., \& Oleinick, N. L. (2003). Association between the photodynamic loss of Bcl-2 and the sensitivity to apoptosis caused by phthalocyanine photodynamic therapy. Photochem. Photobiol. 78, 1-8.

Vohra N., Chavez, T., Troncoso, J. R., Rajaram, N., Wu, J., Coan P. N., Jackson, T. A., Bailey, K. \& El-Shenawee M. (2021). Mammary tumors in Sprague Dawley rats induced by N-ethyl-N-nitrosourea for evaluating terahertz imaging of breast cancer. J. Med. Imag., 8, 2, https://doi.org/10.1117/1.JMI.8.2.023504

Wyld, L.; Reed, M. W. \& Brown, N. J. (2001). Differential cell death response to photodynamic therapy is dependent on dose and cell type. British journal of cancer, 84 , 10, p. 1384-1386.

Xue, L.Y., Chiu, S. M. \& Oleinick, N. (2001). Photochemical destruction of the Bcl-2 oncoprotein during photodynamic therapy with the phthalocyanine photosensitizer Pc 4. Oncogen. 20, 3420-3427.

Yeh, K. T., Chang, J. G., Lin, T. H., Wang, Y.F., Tien, N., Chang, J.Y., et al. (2003). Epigenetic changes of tumor suppressor genes, P15, P16, VHL and P53 in oral cancer. Oncol Rep, 10, 659-663.

Zheng, H. et al. (2019). Elevated serum HER-2 predicts poor prognosis in breast cancer and is correlated to ADAM10 expression. Cancer Medicine, 8, 2, 679685 . 